\title{
Three new species of Isospora Schneider, 1881 (Apicomplexa: Eimeriidae) from the lesser seed-finch, Oryzoborus angolensis (Passeriformes: Emberizidae) from Brazil
}

\author{
Evandro Amaral Trachta e Silva/ ${ }^{++}$, Ivan Literák* , Bretislav Koudela**/***/+
}

\begin{abstract}
Clínica Veterinária Animal, Nova Andradina, MS, Brasil *Department of Biology and Wildlife Diseases
**Department of Parasitology, University of Veterinary and Pharmaceutical Sciences, Palackého 1-3, 61242 Brno, Czech

Republic ***Institute of Parasitology, Biological Centre, Academy of Sciences of the Czech Republic, Èeské Budì jovice,

Czech Republic
\end{abstract}

\begin{abstract}
Three new coccidian (Apicomplexa: Eimeriidae) species are reported from the lesser seed-finch, Oryzoborus angolensis from Brazil. Sporulated oocysts of Isospora curio n. sp. are spherical to subspherical; $24.6 \times 23.6(22-26$ $\times 22-25) \mu \mathrm{m}$, shape-index (SI, length/width) of 1.04 (1.00-1.15). Oocyst wall is bilayerd, $1.5 \mu \mathrm{m}$ thick, smooth and colourless. Micropyle and oocyst residuum are absent. The sporocysts are ovoid, $13.2 \times 10.9(15-17 \times 10-13) \mu \mathrm{m}, \mathrm{SI}$ $=1.56$ (1.42-1.71), with a small Stieda body and residuum composed of numerous granules scattered among the sporozoites. Sporozoites are elongated and posses a smooth surface and two distinct refractile bodies. Oocysts of Isospora braziliensis $n$. sp. are spherical to subspherical, $17.8 \times 16.9(16-19 \times 16-18) \mu m$, with a shape-index of 1.06 (1.00-1.12) and a smooth, single-layered wall $\sim 1 \mu \mathrm{m}$ thick. A micropyle, oocyst residuum and polar granules are absent. Sporocysts are ellipsoid and slightly asymmetric, $13.2 \times 10.8(12-14 \times 9-12) \mu m$, SI = 1.48 (1.34-1.61). Each sporocyst contains a barely visible Stieda body and a residuum composed numerous of granules. Sporozoites are elongated and each of them contains two distinct refractile bodies. Oocysts of Isospora paranaensis $n$. sp. are subspherical to broadly ellipsoid $24.3 \times 19.8(22-26 \times 18-22) \mu \mathrm{m}, \mathrm{SI}=1.22(1.15-1.38)$ with smooth single-layered wall $\sim 1.5 \mu \mathrm{m}$ thick. A micropyle and oocyst residuum are absent, but one distinct ellipsoid polar granule (2.5-3.5 $\times 1.5-2.5 \mu \mathrm{m})$ is present. Sporocyst are ovoid, $15.7 \times 10.1(14-18 \times 8-12) \mu \mathrm{m}, \mathrm{SI}=1.46(1.31-1.72)$, with distinct Stieda and sub-Stieda bodies. Each sporocyst contains a spherical sporocyst residuum, 4 um in diameter. All described isosporan species represent a possible cause of acute coccidiosis for $\mathrm{O}$. angolensis in captivity.
\end{abstract}

Key words: Isospora - curio - lesser seed-finch - Oryzoborus angolensis - Brazil

The lesser seed-finch Oryzoborus angolensis (Linnaeus, 1766) (Passeriformes: Emberizidae) is a bird distributed in open woodland, savanna, bushes, and shrubs in forest edge of Latin America. They are found from North of the Lesser Antilles through Venezuela, Brazil, and Bolivia to South Argentina (Sick 1993). The lesser seedfinches are highly coveted as pet birds and are considered to be among the noblest singing birds. This feature has made this species one of the most highly prized songbirds in Brazil and many birds are bred in captivity. These finches are also frequently trapped from the wild and, consequently, wild lesser seed-finch populations have declined.

No species of Isospora have previously been described in emberizid birds of the genus Oryzoborus. The present study provides descriptions of three new species of Isospora from O. angolensis.

Financial support: Agency of the Czech Republic, grant 524/ 03/H133

+Corresponding author: koudelab@vfu.cz

${ }^{++}$External PhD student at the University of Veterinary nd Pharmaceutical Sciences Brno, Czech Republic

Received 6 March 2006

Accepted 21 June 2006

\section{MATERIALS AND METHODS}

A total of $675 O$. angolensis were examined in this study. The birds originated from 48 private aviaries localized in the state of Mato Grosso do Sul, Brazil. They were reared in suspended cages and individual faecal samples were collected immediately upon defecation on tinfoil on the bottom of the cages at the different day-time. Faecal material was placed in vials containing $2.5 \%(\mathrm{w} / \mathrm{v})$ potassium dichromate solution and shipped to the University of Veterinary and Pharmaceutical Sciences in Brno for follow-up examination. Faecal samples were 3-8 weeks old when screened for coccidia using flotation in Sheather's sugar solution (specific gravity 1.30). The sporulated oocysts were examined and photographed with an Olympus AX 70 microscope using Nomarski interference contrast optics (DIC). All measurements were made using a calibrated ocular micrometer and reported as means in micrometers $(\mu \mathrm{m})$, followed by the range in parentheses.

\section{RESULTS}

During the coprological examination of the $675 O$. angolensis, we detected the presence of oocysts of genus Isospora in 178 birds. The morphological evaluation of sporulated oocysts revealed three different species of Isospora that are described and discussed bellow. 


\section{Isospora curio $\mathrm{n} . \mathrm{sp}$.}

Figs. 1, 2, 7

Description - Oocysts are spherical to subspherical; 24.6 $\times 23.6(22-26 \times 22-25)(\mathrm{n}=30)$, shape-index (SI, length/ width) 1.04 (1.00-1.15). Micropyle and oocyst residuum are absent. Oocyst wall is bilayerd, $\sim 1.5$ thick, smooth and colourless. Sporocysts are ovoid, $13.2 \times 10.9(15-17 \times$ $10-13)(\mathrm{n}=30)$, with a smooth, single-layered wall $\sim 0.5$ thick, sporocyst SI $=1.56(1.42-1.71)$. Stieda body is present, $\sim 0.7$ high $\times 2.0-2.5$ wide, sub-Stidea body is absent. Sporocyst residuum is composed of numerous granules scattered among sporozoites. Sporozoites are elongated, $18.2 \times 3.5(16-19 \times 3-4)(n=12)$, possessing a smooth surface and two distinct refractile bodies. Anterior refractile body is spherical, $\sim 3$ in diameter, the posterior one is elongated, $6.2 \times 3.2(5-7 \times 3.0-3.5)(\mathrm{n}=10)$. The spherical nucleus is situated between the refractile bodies.

Type host - Oryzoborus angolensis (Linnaeus 1766) (Aves: Passeriformes: Emberizidae), the lesser seed-finch.

Type locality - Material was isolated from faeces of captive birds in Mato Grosso do Sul.

Prevalence- $14.66 \%$.

Site of infection - Unknown, oocysts were recovered from faeces.

Sporulation - Exogenous. Time required unknown.

Type material - Photo-syntypes deposited under the depository number A 224 in the Department of Parasitology, University of Veterinary and Pharmaceutical Sciences Brno, Czech Republic.
Etymology - The specific name is derived from the common local name for $O$. angolensis.

\section{Isospora braziliensis n. $\mathrm{sp}$.}

Figs 3, 4, 8

Oocysts are spherical to subspherical, $17.8 \times 16.9(16-$ $19 \times 16-18)(\mathrm{n}=50), \mathrm{SI}=1.06(1.00-1.12)$. Micropyle and oocyst residuum are absent. Oocyst wall is single-layered, $\sim 1.0$ thick, smooth and colourless. Sporocysts are ellipsoid and slightly asymmetric, $13.2 \times 10.8(12-14 \times 9$ $12)(n=30)$, with a smooth, single-layered wall $\sim 0.5$ thick, $\mathrm{SI}=1.48(1.34-1.61)$. Stieda body is present, appearing as a fine plug, $\sim 1$ wide. Sub-Stieda body is absent. Sporocyst residuum composed of numerous granules scattered among sporozoites. Sporozoites are elongated, $13.2 \times 3.1$ $(12-14 \times 2.5-3.5)(\mathrm{n}=10)$, possessing a smooth surface and two distinct refractile bodies. Anterior refractile body is spherical, $\sim 2$ in diameter, the posterior one is elongate, $5.4 \times 2.4(4-6 \times 2.0-3.0)(n=10)$. The spherical nucleus is situated between the refractile bodies.

Type host - Oryzoborus angolensis (Linnaeus 1766) (Aves: Passeriformes: Emberizidae), lesser seed-finch.

Type locality - Material was isolated from faeces of captive birds in Mato Grosso do Sul.

Prevalence- $3.55 \%$.

Site of infection - Unknown, oocysts recovered from faeces.

Sporulation - Exogenous. Time required unknown.

Type material - Photo-syntypes deposited under the de-

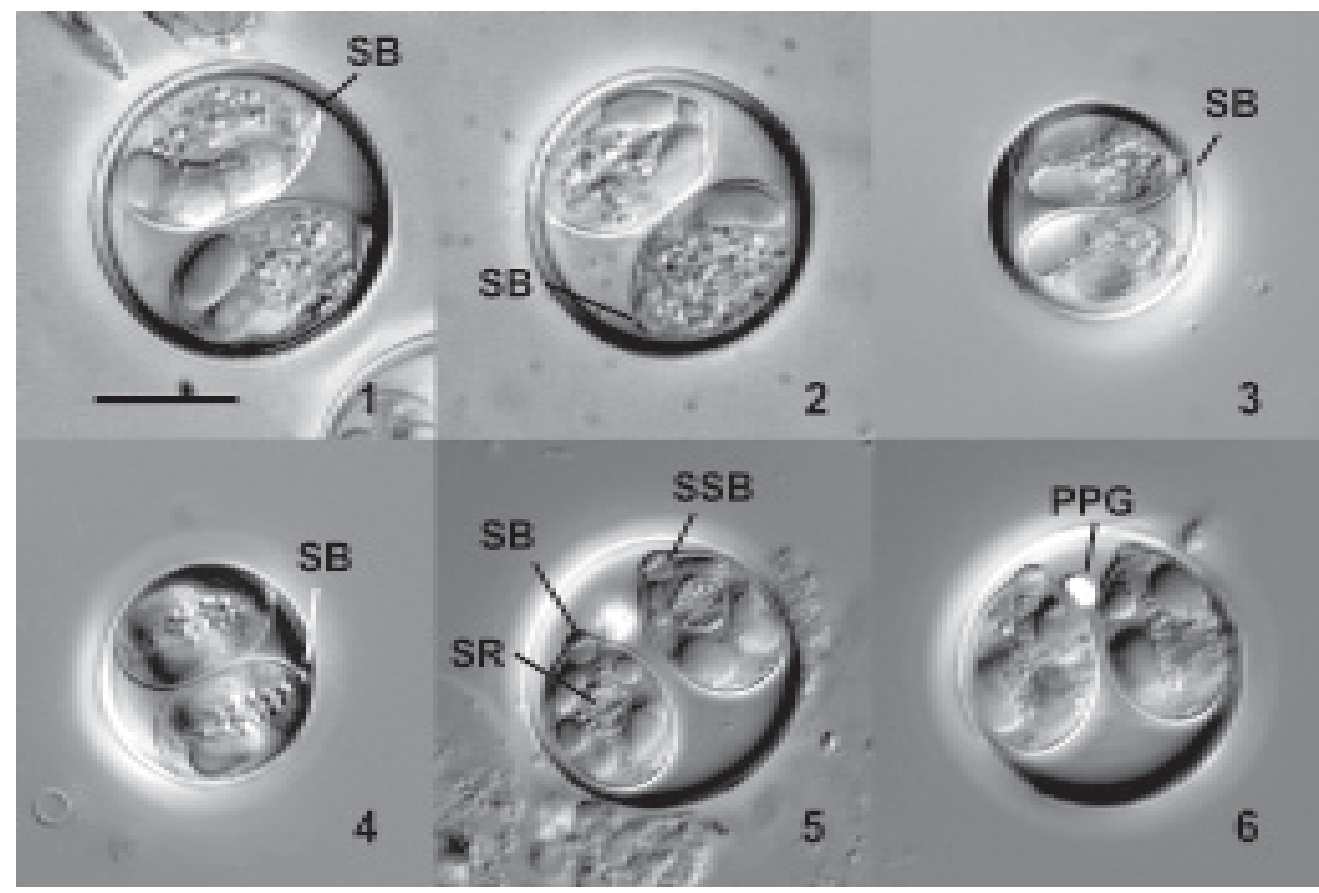

Figs 1-2: Nomarski interference contrast (NIC) photographs of oocysts of Isospora curio n. sp. with delicate Stieda body (SB). Figs 3-4: NIC photographs of oocysts of I. braziliensis n. sp. with a barely visible Stieda body (SB). Figs 5-6: NIC photographs of oocysts of $I$. paranaensis $\mathrm{n}$. sp. with SB, substieda (SSB) bodies and distinct polar granule (PG). Scale bar $=10 \mu \mathrm{m}$. 
pository number B 231 in the Department of Parasitology, University of Veterinary and Pharmaceutical Sciences Brno, Czech Republic.

Etymology - The specific name is derived from the country of origin of the host.

\section{Isospora paranaensis $\mathrm{n} . \mathrm{sp}$}

Figs 5, 6, 9

Oocysts are subspherical to broadly elliptical, $24.3 \times$ $19.8(22-26 \times 18-22),(\mathrm{n}=30), \mathrm{SI}=1.22(1.15-1.38)$. Micropyle and oocyst residuum absent, but one distinct ellipsoid polar granule $(2.5-3.5 \times 1.5-2.5)$ is present. Oocyst wall is single-layered, $\sim 1.5$ thick, smooth and colourless. Sporocyst are ovoid, $15.7 \times 10.1(14-18 \times 8-12)(\mathrm{n}=30)$, with a smooth single-layered wall $\sim 0.5$ thick, $\mathrm{SI}=1.46$ (1.31-1.72). A Stieda body is present, $\sim 1.5 \mathrm{high} \times 2.0-2.5$ wide, sub-Stieda body also present, $~ 2.0-2.5$ high $\times 2.0$ 2.5 wide. A spherical sporocyst residuum is present, $\sim 4$ in diameter, and usually as a cluster of numerous granules. Sporozoites are elongated, $14.9 \times 3.0(13-16 \times 2-4)(n=10)$, possessing a smooth surface and two distinct refractile bodies. Anterior refractile body is spherical, 2-3 in diameter, the posterior one is elongate, $4.8 \times 3.2(4-6 \times 2.5-3.5)$ $(\mathrm{n}=10)$. The spherical nucleus is situated between the refractile bodies.

Type host - Oryzoborus angolensis (Linnaeus 1766) (Aves: Passeriformes: Emberizidae), the lesser seed-finch.

Type locality - Material was isolated from faeces of captive birds in Mato Grosso do Sul.

Prevalence $-1.77 \%$.

Site of infection - Unknown, oocysts recovered from faeces.

Sporulation - Exogenous. Time required unknown.

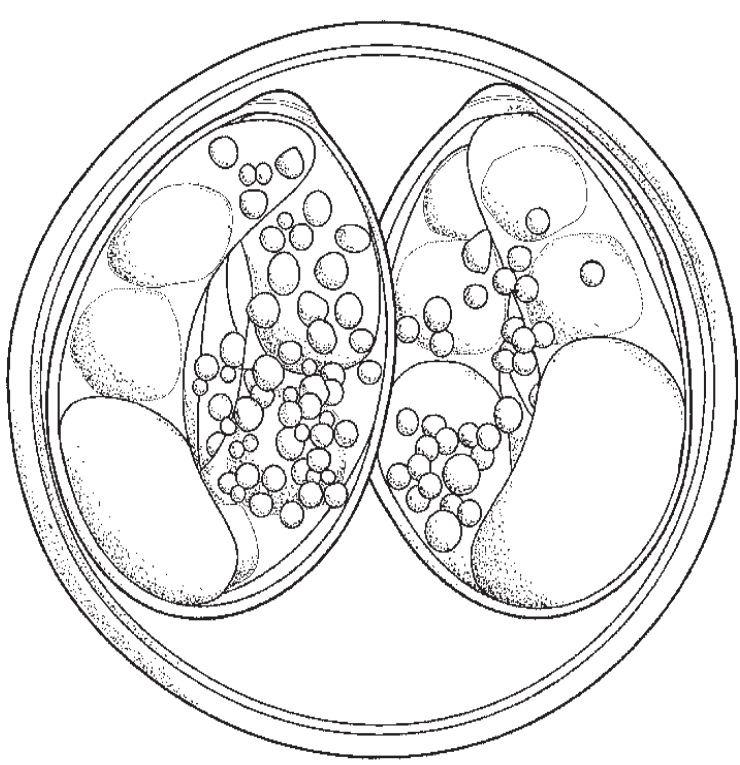

Fig. 7: composite line drawing of sporulated oocyst of Isospora curio n. sp. Scale bar $=10 \mu \mathrm{m}$.

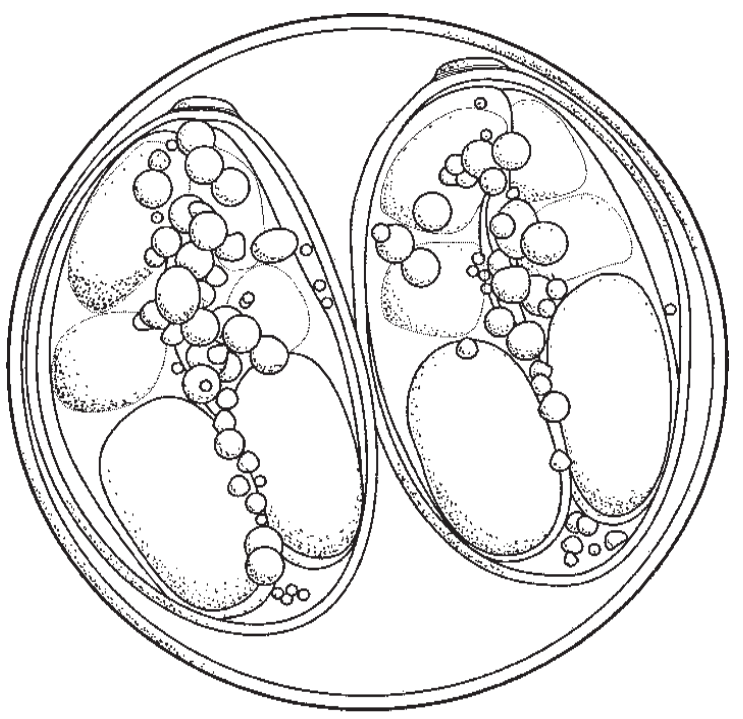

Fig. 8: composite line drawing of sporulated oocyst of Isospora braziliensis $\mathrm{n}$. sp. Scale bar $=10 \mu \mathrm{m}$.

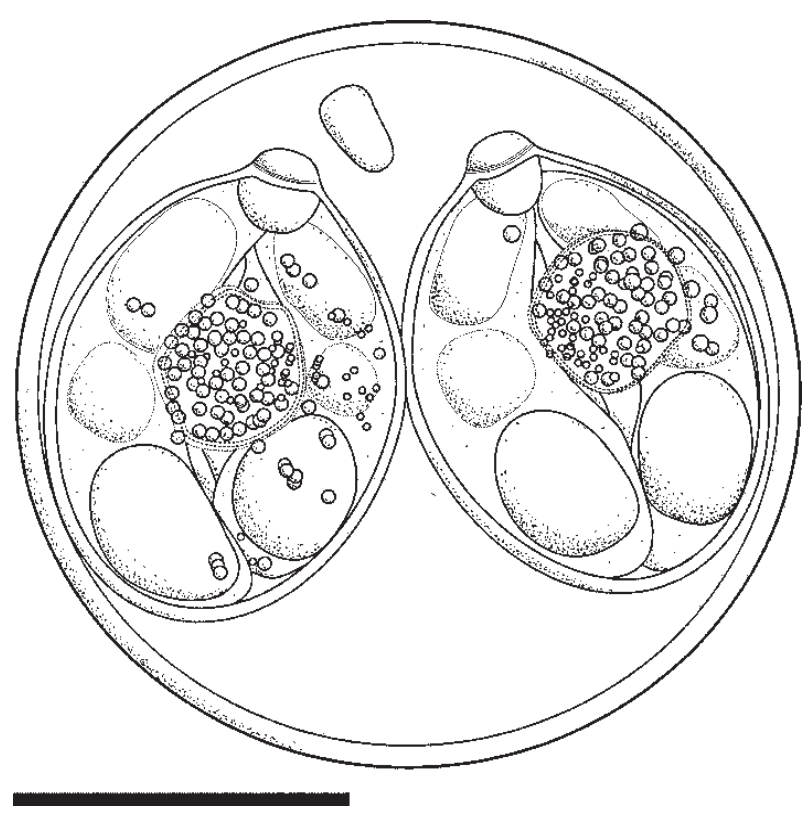

Fig. 9: composite line drawing of sporulated oocyst of Isospora paranaensis $\mathrm{n}$. sp. Scale bar $=10 \mu \mathrm{m}$.

Type material - Photo-syntypes deposited under the depository number B 231 in the Department of Parasitology, University of Veterinary and Pharmaceutical Sciences Brno, Czech Republic.

Etymology - The specific name is derived from the State of Parana, Brazil.

\section{DISCUSSION}

To date, there are around 50 species of Isospora described from emberizids birds (http://www.ksu.edu/para- 
sitology/worldcoccidia/PASSER01?, de Carvalho Filho et al. 2005). However, no named species have been reported from the genus Oryzoborus. We compared the three observed species of Isospora from $O$. angolensis with valid isosporans described from emberizids birds resident in South America or immigrating through this subcontinent and all were found to be different from all the presently described species. These are therefore, considered as new species.

The species most closely resembling I. curio $\mathrm{n}$. sp. are I. formarum McQuistion and Capparella 1992, I. tiaris Ball and Daszak 1997, and I. sporophilae de Carvalho Filho, de Meireles, Ribeiro and Lopes 2005. The sporocysts $I$. formarum, from Pitylus grossus show morphological differences in the presence of a prominent substieda body which is absent in I. curio n. sp. Unlike I. curio n. sp., oocysts of I. tiaris from Tiaris fuliginosa are larger, and the sporocysts possess a prominent sub-Stieda bodies. In contrast, oocysts of $I$. curio n. sp. differ from I. sporophilae of Sporophila caerulescens being larger and having no polar granule.

Oocysts of I. braziliensis n. sp. are similar in size to $I$. flausinoi de Carvalho Filho, de Meireles, Ribeiro and Lopes 2005 and I. teixeirafilhoi de Carvalho Filho, de Meireles, Ribeiro and Lopes 2005, both from S. caerulescens. However, oocysts of of I. braziliensis n. sp. apparently lack a polar granule and the sporocysts are slightly more elongated than those of I. flausinoi and $I$. teixeirafilhoi. In addition, oocysts of I. teixeirafilhoi possess bi-layered oocyst wall, unlike single-layered oocyst wall in I. braziliensis $\mathrm{n}$. sp.

Oocysts of $I$. paranaensis n. sp. are similar in size to $I$. formarum McQuistion and Capparella 1992, I. tiaris Ball and Daszak 1997 and I. sporophilae de Carvalho Filho et al. 2005. However, I. paranaensis $\mathrm{n}$. $\mathrm{sp}$. tends to be broadly ellipsoid, compared with the subspherical oocysts of above mentioned species. In addition, I. paranaensis $\mathrm{n}$. sp. differs from I. formarum in having a distinct polar gran- ule. The oocyst of I. tiaris differs from that of I. paranaensis $\mathrm{n}$. sp. in its morphology, being larger and having morphological differences in the sub-Stieda body and sporocyst residuum. The sporocysts of I. paranaensis $\mathrm{n}$. sp. show morphological differences in the presence of a sub-Stieda body, which is absent in those of $I$. sporophilae.

Based on all above mentioned morphological characteristics, together with host's distribution in nature we consider the species described here to be new coccidian species from captive $O$. angolensis kept in Brazil.

In the present study, coprological examinations indicate a widespread exposure to coccidian parasites among $O$. angolensis in this country. Coccidian infection may be responsible for loss of weight, low reproduction and death in breeding groups of this songbird. Further research should determine the pathology of these coccidial infections in these birds.

\section{ACKNOWLEDGEMENTS}

To Marie Vaòatková for technical assistence.

\section{REFERENCES}

Ball SJ, Daszak P 1997. Isospora tiaras n. sp. (Apicomplexa: Eimeriidae) from the sooty grassquit (Tiaris fuliginosa), a passeriform bird of South America. J Parasitol 83: 465466.

de Carvalho Filho PR, de Meireles GS, Ribeiro CT, Lopes CW 2005. Three new species of Isospora Schneider, 1881 (Apicomplexa: Eimeriidae) from the double-collared seed eater, Sporophila caerulescens (Passeriformes: Emberizidae), from Eastern Brazil. Mem Inst Oswaldo Cruz 100: 151-154.

McQuistion TE, Capparella A 1992. Two new coccidian parasites from the slate-colored grosbeak (Pitylus grossus) of South America. J Parasitol 78: 805-807.

Sick H 1993. Birds in Brazil, A Natural History, Princeton University Press, Princeton, 703 pp. 